\title{
Detection of Six $E$. coli 0157 Virulence Genes in Water Samples Using Multiplex PCR
}

\author{
M.A. El-Leithy ${ }^{\#}$, Einas H. El- Shatoury ${ }^{*}$, W.M. El-Senousy, \\ M.A. Abou-Zeid" and Gamila E. El-Taweel \\ Water Pollution Research Department, Environmental Research \\ Division, National Research Center and "Microbiology \\ Department, Faculty of Science, Ain Shams University, Cairo, \\ Egypt.
}

\begin{abstract}
SCHERICHIA COLI O157 strains have emerged as important human enteric pathogens. E. coli O157 strains may be transmitted in a variety of ways, including drinking water, recreational water and wastewater. One hundred and seventy five water samples were collected from different water sources from June 2010 to July 2011 and examined for classical bacterial indicators (total bacterial counts at $37^{\circ} \mathrm{C}$ and $22^{\circ} \mathrm{C}$, total coliforms, fecal coliforms and fecal streptococci) and E. coli O157. Total coliforms (TC), fecal coliforms (FC) and fecal streptococci (FS) among the collected water samples were 83,76 and 76 out of 175 (MPN- index/100 mL) with incidence ratio of $47 \%, 43 \%$ and $43 \%$, respectively. Escherichia coli $\mathrm{O} 157$ was detected in water samples using HiCrome EC O157:H7 agar and multiplex PCR targeting six virulence genes \{stxl (Shiga toxin 1 gene), stx2 (Shiga toxin 2 gene), eae (intimin gene), hlyA (hemolysin gene), $r f b E$ (O157 antigen gene), and fliC (flagellar antigen gene)\}. The sensitivity test showed that the multiplex PCR amplified genes with a minimum of $100 \mathrm{CFU}$ of $E$. coli O157. Conventional method using HiCrome media indicated that 57 out of 175 examined water samples $(32 \%)$ contained E. coli O157. The multiplex PCR indicated that, 60 water samples were positive for at least one of the six targeted virulence genes. The most prevalent virulence genes in E. coli $\mathrm{O} 157$ isolates were Shiga toxin 2 gene (stx2) (98\%), intimin gene (eae) $(98 \%)$ and 0157 antigen gene $(r f b E)(98 \%)$ followed by Shiga toxin 1 gene $(s t x 1)(84 \%)$ then flagellar antigen gene (flic) (66\%) while Hemolysin gene (hlyA) (0\%) was not detected in any E. coli $\mathrm{O} 157$ isolates.
\end{abstract}

Keywords: E. coli O157, Virulence gene, Multiplex PCR, Water.

Fecal contamination is responsible for the presence of pathogens in natural environment, among which $E$. coli, enteric bacteria, can survive for long periods in the intestinal tracts of warm-blooded animals and also in other environments as faeces (Wang et al., 1996), surface water (Akashi et al., 1994), wastewater (Vernozy-Rozand et al., 2002) and in biofilm (Castonguay et al., 2006). Coliforms (including E. coli) are used as bacterial indicators of fecal contamination of food and water; it can even be representative of the global presence of pathogenic bacteria (Edberg et al., 2000).

${ }^{\#}$ Corresponding author: M. Azab El-Leithy, Water Pollution Research Department, Environmental Research Division, National Research Center, Dokki, Cairo. 12311, Egypt. Phone (+2) 01225110975. E-Mail: mohamedazabr @ yahoo.com 
Escherichia coli O157:H7 causes a wide spectrum of human diseases, including bloody and non-bloody diarrhea, hemorrhagic colitis, occasional kidney failure, hemolytic uremic syndrome (HUS) and death at times (Shelton \& Karns, 2001).

Infection with $E$. coli $\mathrm{O} 157: \mathrm{H} 7$ can be caused by the ingestion of meat (Willshaw et al., 1994), and uncooked fruits and vegetables (Pebody et al., 1999). An outbreak of E. coli O157:H7 infections through drinking water was first reported in the USA in 1989 (Swerdlow et al., 1992) since then E. coli O157 contamination of drinking and recreational water has emerged as important cause of human disease (Chalmers et al., 2000). The presence of E. coli 0157 in drinking water offered to livestock contributes also to the prevalence of infection in animals and may lead to the contamination of meat products and the environment (Elder et al., 2000).

Conventional pathogen detection methods depending on coliform assays are well known for their technical limitations. So, the introduction of PCR technique has allowed for various new approaches in water-borne pathogen research because of its high sensitivity, specificity, and speed as well as the culture independent assay capacity (Lee et al., 2006).

Many detection methods of E. coli $\mathrm{O} 157$ have been employed to rapidly detect low levels of these pathogens in food, beverages and water. Techniques used include traditional enrichment and plating methods with selective media such as Sorbitol MacConkey agar and Rainbow agar (Manafi \& Kremsmaier, 2001 and Meng et al., 2001). Escherichia coli $\mathrm{O} 157$ is particularly difficult to confirm from enrichment cultures due to the problem of high background levels of competing microorganisms including other serotypes of E. coli, so a variety of immunological methods have been developed for the detection and enumeration of E. coli O157 whole bacteria (Park \& Durst, 1999).

A number of PCR based assays have been developed for detection of $E$. coli $\mathrm{O} 157$ in food, water and feces. Some of these assays have targeted only Shiga toxin genes (stx) (Witham et al., 1996). Gannon et al. (1992) developed a duplex PCR procedure to detect Shiga toxin 1 (stxl) and Shiga toxin 2 (stx2) genes. Moreover, several multiplex PCR procedures have been developed to detect different combinations of the major virulence genes. Fagan et al. (1999) included intimin gene (eae) and hemolysin gene $(h l y A)$ to form a four gene PCR reaction to detect eae, hlyA, stxl and stx2 genes. Fratamico et al. (2000) developed five gene multiplex PCR procedures to detect different combinations of fliC, stxl, stx2, eae, hlyA and $r f b E$. Two separate multiplex PCR procedures, described by Gannon et al. (1997) and Fagan et al. (1999) were routinely used, to identify the five genes, eae, stxl, stx2, hlyA and fliC. Bai et al. (2010) developed a multiplex PCR procedure that can detect six virulence genes (fliC, stx 1, stx 2 , eae, $r f b E$ and $h l y A$ ) of $E$. coli $\mathrm{O} 157$. So this study was aimed to detect $E$. coli $\mathrm{O} 157$ using both multiplex PCR and HiCrome EC O157:H7 agar from water samples. In addition to, characterize E. coli $\mathrm{O} 157$ using multiplex PCR targeting six virulence genes (fliC, stxl, stx2, eae, $r f b E$ and $h l y A$ ) to determine the most frequent virulence gene in Egyptian aquatic environment.

Egypt. J.Microbiol. 47 (2012) 


\section{Materials and Methods}

Sampling sites

One hundred and seventy five water samples were collected from different water sources in Egypt having a wide range of microbial load during the period June 2010 to July 2011, the samples included: 50 surface water samples from 10 sites $2 \mathrm{~km}$ along the River Nile (Rossita Branch) (around mixing point with ElRahawy Drain), 20 water samples from El-Rahawy Drain along $5 \mathrm{~km}$, ten raw wastewater samples from El-Kasr El- Aini Hospital, 40 untreated groundwater samples (New Valley Governorate), 40 treated groundwater samples (Kalubyia Governorate) and fifteen sea water samples from Mediterranean Sea at Marsa Matroha Governorate. Depending on water source, a quantity of $1 \mathrm{~L}-20 \mathrm{~L}$ volume water samples were collected in sterile sampling bottles, then transferred to laboratory at National Research Center (NRC) within 1-8 hr in ice box.

\section{Microbiological examination}

Detection and enumeration of classical bacterial indicators; total bacterial counts (TBC), TC, FC and FS were carried out according to American Public Health Association (APHA, 2005) using pour plate technique for TVBC and multiple tube fermentation technique (MTF) for TC, FC and FS. The detection of E. coli $\mathrm{O} 157$ was carried out using HiCrome EC O157:H7 selective agar base (HiMedia, India) plates supplemented with novobiocin and potassium tellurite (HiMedia, India). Typical colonies of E. coli $\mathrm{O} 157$ isolates were confirmed by subculturing on HiCrome MacConky Sorbitol agar base (HiMedia, India) supplemented with tellurite and cefixime (HiMedia, India) and incubated at $37^{\circ} \mathrm{C}$ for $24 \mathrm{hr}$. Indole and oxidase tests (APHA, 2005) were also performed to confirm the E. coli $\mathrm{O} 157$ isolates.

PCR sensitivity test on E. coli O157:H7

The PCR sensitivity test was carried out using E. coli O157:H7 (ATCC 35150) obtained from VACSERA Co., Egypt as a positive control. The positive control was centrifuged at $3000 \mathrm{rpm}$ for $15-20 \mathrm{~min}$. The pellets were resuspended in phosphate buffered saline (PBS), two portions of 10-fold serial dilutions (from $10^{-1}-10^{-9}$ ) were prepared. Each portion was tested using multiplex PCR and another portion counted using standard plate count agar.

PCR specificity test on E. coli O157:H7

The primer specificity of multiplex PCR was carried out using E. coli O157:H7 (ATCC 35150) as positive control. While negative controls included $E$. coli (ATCC 25922), Enterobacter cloacae, Klebsiella pneumonia, Proteus mirabilis, Listeria monocytogenes (ATCC 25152), Salmonella enterica serovar Typhimurium (ATCC 14028), Pseudomonas aeurgniosa, Staphylococcus aureus and $E$. coli all negative controls were obtained from Bacteriology Lab., Water Pollution Research Department, National Research Center, Egypt. Both postive and negative controls were incubated at $37^{\circ} \mathrm{C}$ for $18-24 \mathrm{hr}$ in tryptic soya broth (TSB), then centrifuged at $3000 \mathrm{rpm}$ for $15-20 \mathrm{~min}$; washed twice by sterile PBS pellets resuspended in $1 \mathrm{~mL}$ of PBS, DNA extracted and multiplex PCR carried out according to the procedure described below. 
DNA extraction of E. coli $O 157$ isolates

The DNA extraction of $E$. coli $\mathrm{O} 157$ isolates was carried out according to Bai et al. (2010), One colony of each isolate was suspended in one $\mathrm{mL}$ of sterile distilled water and boiled for $10 \mathrm{~min}$ then preserved in ice for $5 \mathrm{~min}$. After centrifugation at $12000 \mathrm{rpm}$ for $10 \mathrm{~min}, 300-500 \mu \mathrm{L}$ of supernatant transferred to eppendorf, $5 \mu \mathrm{L}$ of supernatant were used as template in multiplex PCR reaction.

\section{Preparation of water samples for PCR}

Water samples were filtered with nitro-cellulose membrane $(0.2 \mu \mathrm{m}$ pore size and $47 \mathrm{~mm}$ in diameter (Whattman Co.)). The membrane filter was transferred to $10 \mathrm{~mL}$ TSB with $10 \%$ glycerol plate. Plates were incubated overnight at room temperature with gently shaking. DNA extractions were carried out according to the methods described by Kapperud et al. (1993) and Waage et al. (1999).

\section{Selection and synthesis of primers}

Detection of E. coli $\mathrm{O} 157$ by multiplex PCR was carried out according to many authors (Table 1) using primers targeting six virulence genes of $E$. coli O157 as follow, stxl (Shiga toxin 1 gene), stx2 (Shiga toxin 2 gene), eae (intimin gene), hlyA (hemolysin gene), rfbE (O157 antigen gene) and fliC (flagellar antigen gene) in one microtube. The primers of this study were synthesized by Bio-Basic Inc., Canada.

\section{PCR condition optimization}

Multiplex PCR conditions were carried out according to Bai et al. (2010); however no DNA amplification were carried out to obtain PCR products, so different conditions were used to reach an optimal condition. Multiplex PCR in this study was used in two ways; first one to confirm and characterize the suspected colonies of E. coli $\mathrm{O} 157$, another way directly detect $E$. coli $\mathrm{O} 157$ in water samples. All PCR reactions were performed in TC-S thermal cycler (BOECO, Germany). Multiplex PCR was first tested individually on E. coli O157 (ATCC 35150). Factors tested include; primer concentration over a range of $0.1-0.5 \mu \mathrm{M}$., the dNTPs concentration over a range of $200-400 \mu \mathrm{M}$., annealing temperatures over a range $50-65^{\circ} \mathrm{C}$, Taq DNA polymerase concentration over a range 2- 4 units and PCR cycle number over a range 25- 35 cycles. After a series of tests, the following optimal conditions for the six gene multiplex PCR procedure were established as: reaction volume of $50 \mu \mathrm{L}$ consisting of $5 \mu \mathrm{L}$ of DNA template and $45 \mu \mathrm{L}$ master mix (BioFlux) from $5 \mu \mathrm{L}$ of 10X PCR buffer (containing $7.5 \mathrm{mM}$ of $\mathrm{MgCl}_{2}, 50 \mathrm{mM}$ of KCl, $20 \mathrm{mM}$ of Tris- $\mathrm{HCl}(\mathrm{pH} 8.4)$ ), $0.5 \mu \mathrm{L}$ from each primer (mixture of equal amount of the $100 \mathrm{mM}$ primer stocks), $250 \mu \mathrm{M}$ of dNTPs, and 4 units of Taq DNA polymerase (Bio-Rad, CA). The PCR program used after optimization was: $94^{\circ} \mathrm{C}$ denaturation for $3 \mathrm{~min}, 35$ cycles of $94^{\circ} \mathrm{C}$ denaturation for $30 \mathrm{~s}, 60^{\circ} \mathrm{C}$ annealing for $30 \mathrm{~s}, 72^{\circ} \mathrm{C}$ extension for $75 \mathrm{~s}$, and a final step of $72^{\circ} \mathrm{C}$ extension for $5 \mathrm{~min}$. The amplified DNA was separated on $2 \%$ agarose gel and stained with $0.5 \mu \mathrm{g} / \mathrm{mL}$ of ethidium bromide with Ladder $\Phi X 174 \mathrm{DNA} / \mathrm{HaeIII}$ digest (TOYOBO, Japan). The DNA bands were visualized and documented with a GelDoc UVP Fluorescent Imaging System (UVP, UK).

Egypt. J.Microbiol. 47 (2012) 
DETECTION OF SIX E. COLI O157 VIRULENCE ...

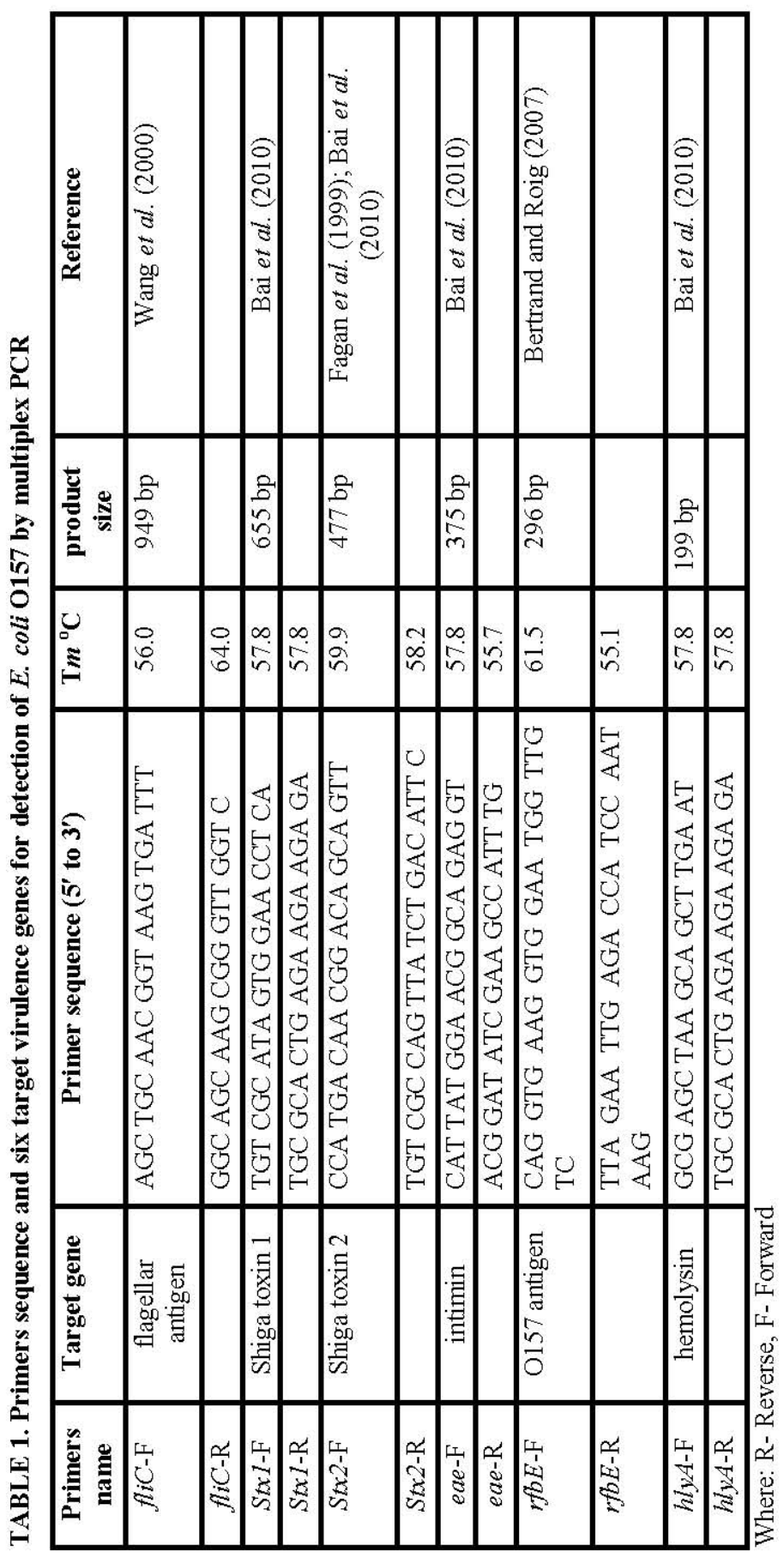

Egypt. J.Microbiol. 47 (2012) 
Sensitivity and specificity test

\section{Results}

The sensitivity of multiplex PCR was assessed using serial dilution of E. coli O157:H7 (ATCC 35150) suspended in PBS (Table 2). The detection limit of $E$. coli $\mathrm{O} 157$ (showing clear PCR product) by multiplex PCR was 100 CFU. Dilutions from stock to $10^{-4}$ showed four PCR positive products namely Shiga toxin 1 gene (stx1), Shiga toxin 2 gene (stx2), intimin gene (eae) and O157 antigen gene $(r f b E)$, respectively. Further dilutions from $0^{-5}$ to $10^{-7}$ revealed the disappearance of Shiga toxin 1 gene (stx 1$)$ only, whereas the last two dilutions $\left(10^{-8}\right.$ and $\left.10^{-9}\right)$ lacked all PCR products (Fig. 1).

The specificity of multiplex PCR was carried out using both positive and negative controls. PCR products of positive control (Lane 2) showed bands of Shiga toxin 2 gene (477 bp), intimin gene (375 bp) and 0157 antigen gene (296 bp). On the other hand, the negative controls strains showed no PCR products for any of the negative controls (Fig. 2).

TABLE 2. E. coli O157:H7 cell number limits for PCR detection .

\begin{tabular}{|l|c|c|}
\hline Dilution & Average CFU/mL & PCR \\
\hline Stock & TNTC & + \\
\hline $10^{-1}$ & TNTC & + \\
\hline $10^{-2}$ & $8.9 \times 10^{4}$ & + \\
\hline $10^{-3}$ & $2.1 \times 10^{4}$ & + \\
\hline $10^{-4}$ & $6.3 \times 10^{3}$ & + \\
\hline $10^{-5}$ & $2.1 \times 10^{3}$ & + \\
\hline $10^{-6}$ & $2.1 \times 10^{2}$ & + \\
\hline $10^{-7}$ & $1.0 \times 10^{2}$ & + \\
\hline $10^{-8}$ & 25 & - \\
\hline $10^{-9}$ & Zero & - \\
\hline
\end{tabular}

TNTC: Too Numerous To Count

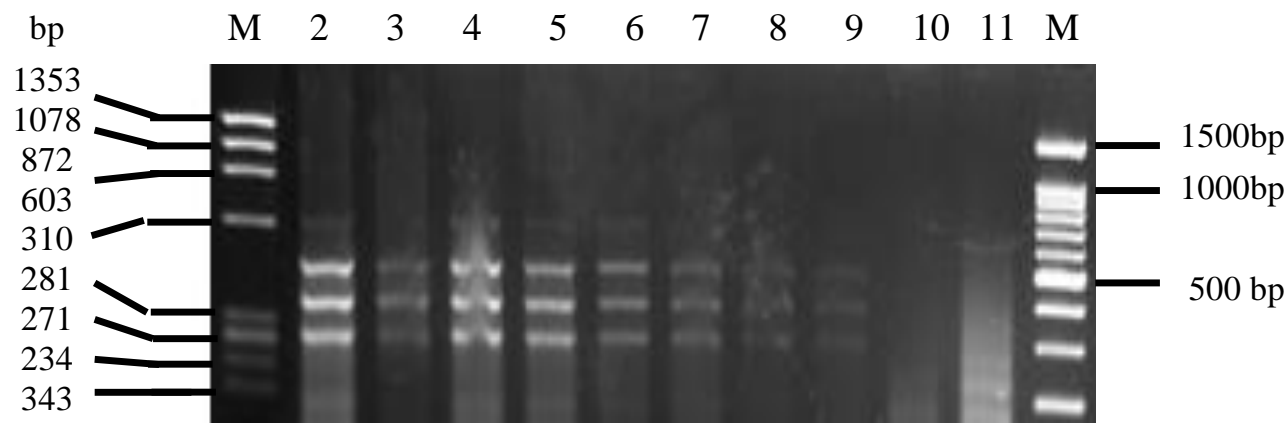

Fig. 1. Sensitivity test of multiplex PCR, Lane M: ØX 174 ladder, Lane 2: Stock, Lanes 3- 11: serial dilution from $10^{-1}-10^{-9}$, lane M: 100 bp DNA Ladder RTU.

Egypt. J.Microbiol. 47 (2012) 


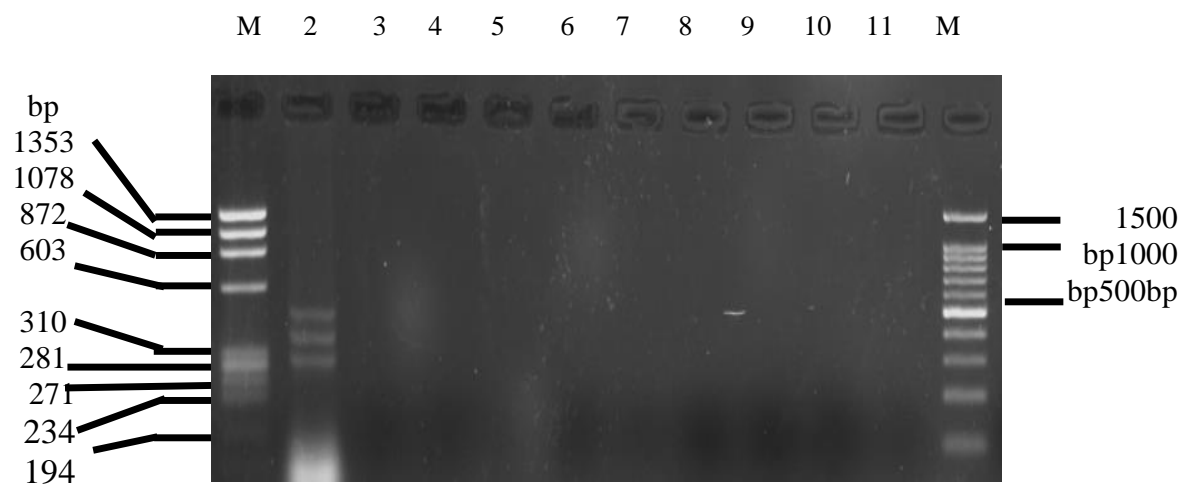

Fig. 2. Specificity test of multiplex PCR.

Lane M: ØX174 ladder, Lane 2: positive control E. coli O157 (ATCC 35150), Lane 3: E. coli (ATCC 25922), Lane 4: Enterobacter cloacae, Lane 5: Klebsiella pneumonia, Lane 6: Proteus mirasbilis, Lane 7: Listeria monocytogenes (ATCC 25152), Lane 8: Salmonella Typhimurium (ATCC 14028), Lane 9: Pseudomonas aeurgniosa, Lane 10: Staphylococcus aureus, Lane 11: E. coli, Lane M: 100 bp DNA Ladder RTU.

Detection of bacterial indicators and E. coli O157 in different water samples

Results in Table 3 show the range and average counts of bacterial indicators; total viable bacterial counts at $37^{\circ} \mathrm{C}$ and $22^{\circ} \mathrm{C}$, total coliforms, fecal coliforms and fecal streptococci (MPN-index $/ 100 \mathrm{~mL}$ ) and the range and average counts of the selected pathogenic E. coli O157 (CFU/100 mL) using HiCrome EC O157 medium. The counts varied according to water source, the highest counts were found in El-Rahawy Drain for bacterial indicators and E. coli O157 followed by River Nile, then hospital wastewater. Both TC and FC were detected in untreated ground water but FS and E. coli $\mathrm{O} 157$ were not detected. Whereas the treated ground water and sea water showed absence of TC, FC, FS and E. coli O157. E. coli $\mathrm{O} 157$ was detected in 57 out of 175 examined water samples (32\%) using HiCrome EC 0157 medium while the multiplex PCR indicated that, 60 out of 175 examined water samples $(34 \%)$ were positive for at least one of the six targeted virulence genes (Table 4).

In River Nile water; the prevalence of TC, FC, FS and E. coli $\mathrm{O} 157$ were 50 $(100 \%), 45(90 \%), 46(92 \%)$ and $32(64 \%)$, respectively. From the multiplex PCR results, it was found that, E. coli $\mathrm{O} 157$ was positive in $35(70 \%)$, the presence of six virulence genes (flic, stxl, stx2, eae, rfbE and $h l y)$ was $0(0 \%), 10$ (20\%), $25(50 \%), 23(46 \%), 15(30 \%)$ and $0(0 \%)$, respectively (Table 4).

In case of El- Rahawy drain samples, the prevalence of TC, FC, FS and $E$. coli $\mathrm{O} 157$ was 20 out of $20(100 \%)$. The multiplex PCR results confirmed such prevalence of E. coli $\mathrm{O} 157$ was detected in 20 out of 20 water samples with prevalence percentage $100 \%$ and the presence of six virulence genes (flic, stxl, st $x 2$, eae, $r f b E$ and $h l y)$ was 1 (5\%), 8 (40\%), $17(85 \%), 19(95 \%), 15(75 \%)$ and $1(5 \%)$, respectively (Table 4$)$. 


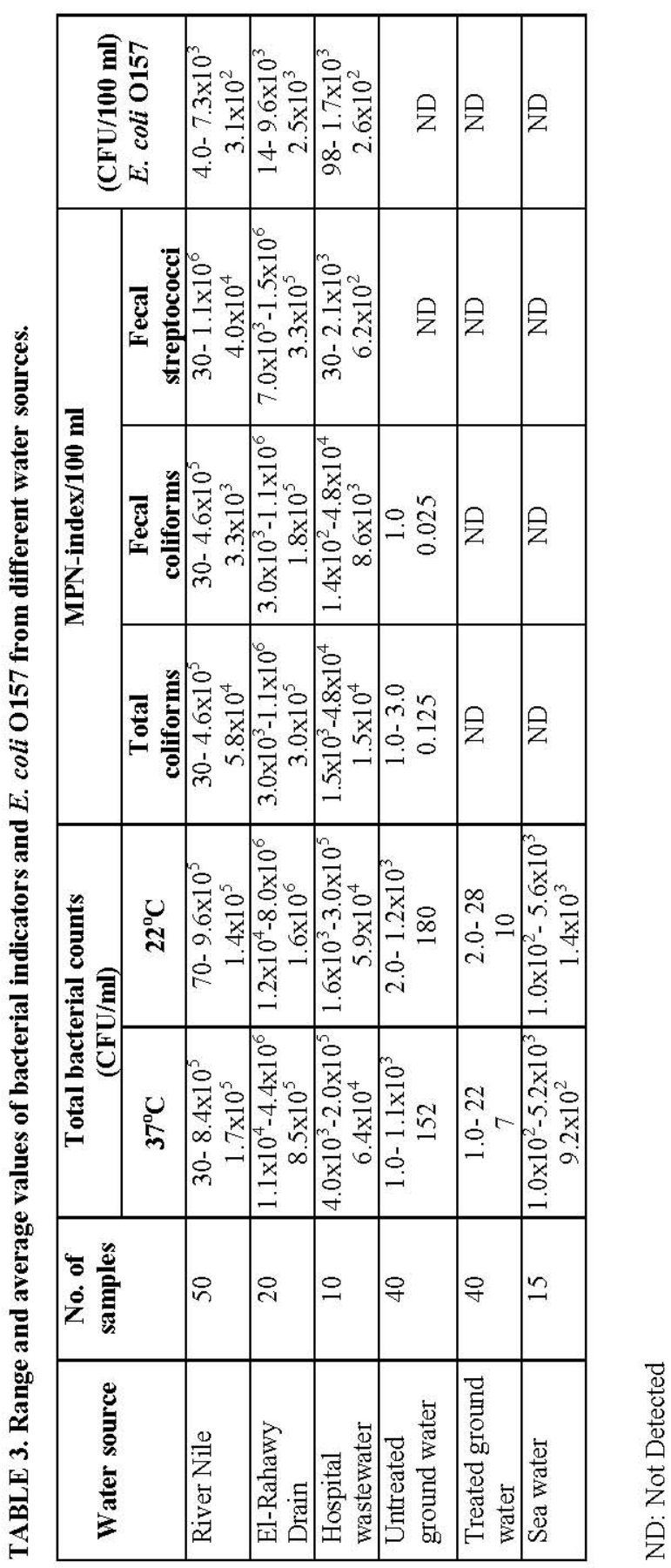

Egypt. J.Microbiol. 47 (2012) 
DETECTION OF SIX E. COLI O157 VIRULENCE ...

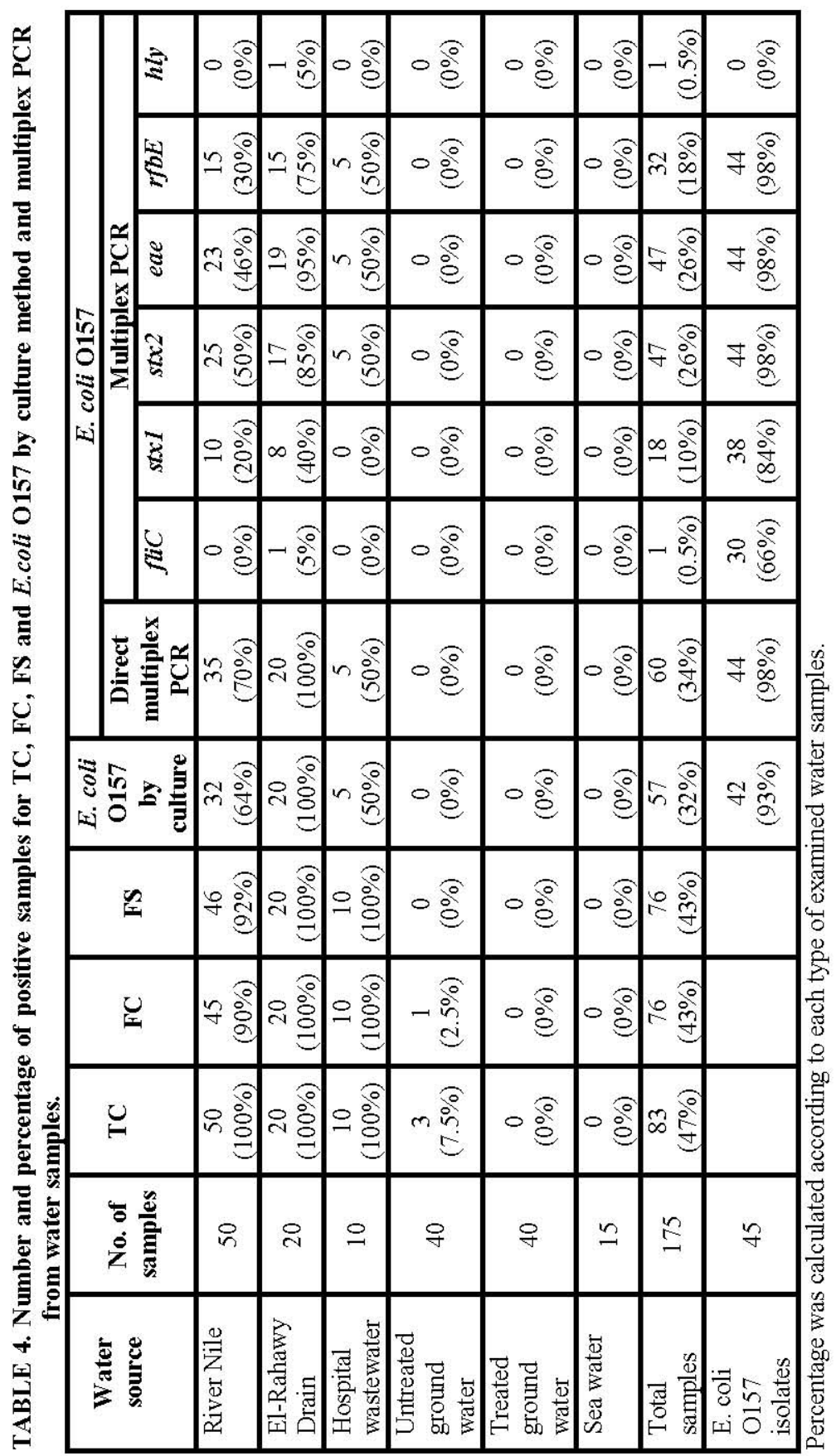

Egypt. J.Microbiol. 47 (2012) 
In hospital wastewater samples, the presence of TC, FC and FS was detected in 10 out of $10(100 \%)$ wastewater samples and E. coli $\mathrm{O} 157$ was positive in 5 out of $10(50 \%)$ using both culture method and multiplex PCR with only three detected virulence genes (stx2, eae and $r f b E$ ) (Table 4).

Escherichia coli $\mathrm{O} 157$ was not detected in untreated, treated ground water and sea water either by the conventional cultivation methods or by PCR technique (Tables 3, 4). Generally, the occurrences of TC, FC and FS in the collected water samples were 83, 76 and 76 with incidence of $47 \%$, 43\% and $43 \%$, respectively. E. coli O157 was detected in 57 (32\%) and 60 (34\%) by cultural methods and multiplex PCR, respectively. From the multiplex PCR results, the characterizations of six virulence genes (flic, stx l, stx2, eae, rfbE and hly) were: 1 (0.5\%), 18 (10\%), 47 (26\%), $47(26 \%), 32(18 \%)$ and $1(0.5 \%)$, respectively. The most dominant virulence gene in different water samples was the Shiga toxin 2 gene (stx2) and the intimin gene (eae) followed by O157 antigen $(r f b E)$ gene, Shiga toxin 1 gene $(s t x 1)$ then flagellar antigen (flic) gene and hemolysin (hly) gene (Table 4). Fourty- five random E. coli O157 isolates were confirmed as; indole positive, oxidase negative and non-sorbitol fermenting. The confirmed isolates were regarded as presumptively positive $E$. coli O157. Using biochemical and multiplex PCR, 42 (93\%) and 44 (98\%), respectively were further confirmed as E. coli O157 (Table 4 and Fig. 3). The characterization of 44 E. coli $\mathrm{O} 157$ isolates by multiplex PCR was: 30 (66\%), 38 (84\%), $44(98 \%), 44(98 \%), 44(98 \%)$ and $0(0 \%)$ positive for six virulence genes (flic, stxl, stx2, eae, $r f b E$ and $h l y$ ), respectively.

Sequence analyses of six PCR positive E. coli $\mathrm{O} 157$ showed that the most frequent strains were $E$. coli O157:H7 strains (acc.no.NZ DS 571135.1 and NZ KB 453139.1) with high homology.

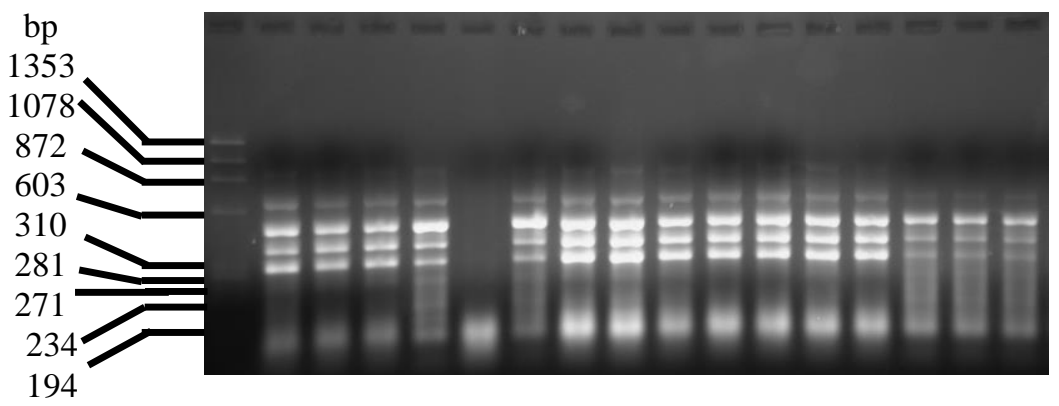

Fig. 3. Multiplex PCR of $E$. coli 0157 isolates Lane M: ØX 174 ladder, Lane 2- 5: $E$. coli 0157 isolates Lane 6: negative control Listeria monocytogenes (ATCC 25152), Lane 7- 17: E. coli 0157 isolates. 


\section{Discussion}

Waterborne diseases have been regarded as a major global health problem throughout history. Microbial contamination remains a critical risk factor in water in many parts of the world, municipal sewage become the conduits for the passage of pathogens into surface water (Irvine el al., 1995), Escherichia coli $\mathrm{O} 157$ is waterborne pathogen that has emerged as a major cause of hemorrhagic colitis and is transmitted to humans either by food or water, it can cause HUS mainly by secretion of Shiga toxins encoded by the virulence genes stxl and/or stx 2 and others variants (Bidet et al., 2005). The human infectious dose is very low, and ingestion of amounts as few as 10 cells is thought to be sufficient to cause illness (Chart, 2000).

The last decade has seen a significant increase in the development of PCR techniques for the rapid detection of water-borne human pathogens including $E$. coli $\mathrm{O} 157$ (Cupples et al., 2010). PCR reactions are designed to either amplify a single product (Fincher et al., 2009) or to use several primer pairs as part of a multiplex PCR (Campbell et al., 2001). The advantage of multiplex PCR is the capacity to simultaneously detect a number of sequences from the target organism (Osek, 2003 and Duris et al., 2009); to detect several pathogenic species in a single sample (Kong et al., 2002) or to detect critical virulence factors, e.g. stxl and stx2, which are involved in the production of the Shiga toxin, or eae which codes for intimin (Bopp et al., 2003; Osek, 2003; GarciaAljaro et al., 2004 and Quilliam et al., 2011). This study used multiplex PCR in comparison with HiCrome EC O157:H7 agar to detect E. coli O157 in different water samples. In addition to, characterize E. coli $\mathrm{O} 157$ using multiplex PCR through targeting six virulence genes (fliC, stx $1, s t x 2$, eae, $r f b E$ and $h l y A)$ in order to determine the most frequent virulence gene in Egyptian aquatic environment. With regard to the results of bacterial indicators, TC, FC and FS were detected in 83,76 and 76 out of 175 water samples, respectively, these data revealed a high incidence of microbial load along El-Rahawy Drain and River Nile (Rossita Branch). A possible explanation that El- Rahawy Drain receives agriculture wastewater from surrounding fields in El-Rahawy village beside that, it receives large amount of treated wastewater from Zenin and Abou-Rawash wastewater treatment plants from Greater Cairo that are discharging directly into Rossita Branch. In Egypt, El- Jakee et. al. (2009) reported that, 90\% of the collected water samples were positive for coliform group reached to $>1800$ MPN- index/100 mL and the highest coliforms detection was recorded among samples collected from Baniswaf, Mansoria and Maruotia canals followed by drinking underground water (Gezera El Dahab, El Zomor and Kerdasa), River Nile, agriculture drain, untreated sewage water, treated sewage water and well samples with values of $24,18,16,14,8,6$ and $4 \%$, respectively.

In the present study the detection limit of E. coli $\mathrm{O} 157$ was $100 \mathrm{CFU}$ by multiplex PCR (Table 2). E. coli O157 was detected in $32 \%$ and $34 \%$ water 
samples using cultural methods and multiplex PCR, respectively. From the results, it was found that $E$. coli $\mathrm{O} 157$ was detected in 57 and 60 out of 176 water samples using HiCrome EC O157 agar medium and multiplex PCR respectively; it means that the multiplex PCR was more sensitive than the cultivation methods in our study. E. coli O157:H7 strains (acc.no.NZDS 571135.1 and NZ KB 453139.1) were observed in the sequenced samples it means that E. coli O157:H7 was the most frequent in El- Rahawy drain water samples it may be due to receiving agriculture wastewater from surrounding fields in El-Rahawy village beside that, it receives large amount of treated wastewater and also presence of animal, cattles and rodents. The multiplex PCR, results, confirmed the characterization of six virulence genes (flic, stxl, stx2, eae, rfbE and hly) frequent in water samples were: $1(0.5 \%), 18(10 \%), 47(26 \%), 47(26 \%), 32$ $(18 \%)$ and $1(0.5 \%)$, respectively. The most dominant virulence gene was the Shiga toxin 2 gene (stx2) and intimin gene (eae). Campbell (2001) reported that, a multiplex PCR, which was able to detect viable cells and to distinguish the serotype $\mathrm{O} 157: \mathrm{H} 7$ was used to confirm the presence of E. coli $\mathrm{O} 157: \mathrm{H} 7$ in soil and water. Moreover, the author reported that detection limits were $1 \mathrm{CFU} \mathrm{mL}^{-1}$ in drinking water and $2 \mathrm{CFU} \mathrm{g}^{-1}$ soil. Bai et al. (2010) used the same six primers (used in this study) to test 84 cattle fecal and 57 human clinical E. coli 0157 strains for detecting the following six genes (fliC, stxl, stx2, eae, rfbE and hlyA). The 84 cattle strains differed only in stxl and stx 2 genes, and all possessed the other four genes. Among the cattle strains, $28 \%$ had stx $2,26 \%$ had stxl, and $28 \%$ had both stxl and stx2. Similarly all the 57 human strains (100\%) possessed fliC, $e a e, r f b E$ and $h l y A$ and differed in stxl and stx2. Of the 57 human strains, 38\% had both stxl and stx2, 60\% had stx2 and only $2 \%$ had stxl alone. In the same study, both cattle and human strains were also tested with an O157-specific agglutination $(r f b E)$ followed by the two separate multiplex PCR procedures on fliC, stxl, stx2, eae and hlyA genes. Bai et al. (2010) added that, sensitivity tests showed that the procedure amplified genes from a fecal sample spiked with a minimum of $104 \mathrm{CFU} / \mathrm{g}$ (10 cells/reaction) of E. coli O157. After a 6-h enrichment period of E. coli $\mathrm{O} 157$ spiked samples, a sensitivity level of 10 $\mathrm{CFU} / \mathrm{g}$ was achieved.

In Egypt, El-Safey (2001) found specific shiga-like toxin (stxl and stx2), intimin (eaeA) and the enterohemorrhagic E. coli hemolysin (hlyA) genes in five E. coli $\mathrm{O} 157: \mathrm{H} 7$ strains isolated from Egyptian food. Whereas, In South Africa Müller et al. (2003) reported a prevalent rate of 20\% E. coli $\mathrm{O} 157: \mathrm{H} 7$ from sewage and environmental sources.

In France, Bertrand \& Roig (2007) used a specific and sensitive PCR assay based on the $r f b E$ gene to detect low levels of E. coli $\mathrm{O} 157$ in wastewater. The set of primers used was designed to amplify an intragenic segment of the $r f b E$ gene. The amplification assay detected $200 \mathrm{CFU}$ of E. coli $\mathrm{O} 157$ in pure water. The prevalence of $E$. coli $\mathrm{O} 157$ in the effluents of 44 wastewater treatment plants was determined (7\%). 
El- Jakee et al. (2009) mentioned that, from 14 E. coli strains isolated from different water sources in Egypt and characterized by monoplex PCR as follow 8 $(57.1 \%)$ isolates carried stxl and $4(28.6 \%)$ possessed $s t x 2$ gene. Intimin (eae), fliCh 7 and $h l y$, virulence genes were detected in $3(21.4 \%)$, whereas hly gene was found in 4 (28.6\%) of the isolates. In Saudi Arabia, Abulreesh (2011) found that, $2.5 \%$ of 400 pigeon fecal samples were positive Shiga toxin- producing $E$. coli.

In conclusion, the cultivation on HiCrome media is considered inexpensive and reliable methods for the detection of E. coli $\mathrm{O} 157$ in concentrated water sample; samples with low counts (4 CFU/100mL) where easily detected. The multiplex PCR using selected primers targeting virulence genes of $E$. coli $\mathrm{O} 157$ offers more accurate and convenient methods for rapid detection of pathogenic E. coli and provides a clue for the degree of virulence. Although, the most frequent genes obtained in this study were Shiga toxin 2 gene (stx2), Intimin gene (eae) and 0157 antigen gene $(r f b E)$, It is recommended to optimize the PCR conditions to target as many as possible genes under investigation. At last, the type's numbers of the present genes, reflect the severity of the suspected infection.

\section{Reference}

Abulreesh, H.H. (2011) Free living rock pigeon (Columba livia) as an environmental reservoir of entric bacterial pathogens resistant to antimicrobial drugs in Saudi Arabia. Curr. Res. Bacteriol. 4, 28-33.

Akashi, S., Joh, K., Tsuji, A., Ito, H., Hoshi, H., Hayakawa, T., Ihara, J., Abe, T., Hatori, M. and Mori, T. (1994) A severe outbreak of haemorrhagic colitis and haemolytic uraemic syndrome associated with E. coli O157:H7 in Japan. Eur. J. Pediatr. 153 (9), 650- 655.

APHA (American Public Health Association) (2005) "Standard Methods For The Examination of Water and Wastewater", $21^{\text {st }}$ ed. Washington, D.C.

Bai, J., Xiaorong-Shi and Nagaraja, T.G. (2010) A multiplex PCR procedure for the detection of six major virulence genes in Escherichia coli O157:H7. Microbiol. Meth. 82, 85- 89 .

Bertrand, R. and Roig, B. (2007) Evaluation of enrichment-free PCR-based detection on the $r f b E$ gene of Escherichia coli $\mathrm{O} 157$ application to municipal wastewater. Water Res. 41, 1280-1286.

Bidet, P., Mariani-Kurkdjian, P., Grimont, F., Brahimi, C., Grimont, P. and Bingen, E. (2005) Characterization of E. coli $\mathrm{O} 157: \mathrm{H} 7$ isolates causing haemolytic uraemic syndrome in France. Medical Microbiol. 54, 71-75. 
Bopp, D.J., Sauders, B.D., Waring, A.L., Ackelsberg, J., Dumas, N., Braun-Howland, E., Dziewulski, D., Wallace, B.J., Kelly, M., Halse, T., Musser, K.A., Smith, P.F., Morse, D.L. and Limberger, R.J. (2003) Detection, isolation, and molecular subtyping of Escherichia coli O157:H7 and Campylobacter jejuni associated with a large waterborne outbreak. Clin. Microbiol. 41, 174-180.

Campbell, G.R., Prosser, J., Glover, A. and Killham, K. (2001) Detection of Escherichia coli $\mathrm{O} 157: \mathrm{H} 7$ in soil and water using multiplex PCR. Appl. Microbiol. 91, 1004-1010.

Castonguay, M.H., van der Schaaf, S., Koester, W., Krooneman, J., van der Meer, W., Harmsen, H. and Landini, P. (2006) Biofilm formation by E. coli is stimulated by synergistic interactions and co-adhesion mechanisms with adherence-proficient bacteria. Res. Microbiol. 157(5), 471- 478.

Chalmers, R.M., Aird,H. and Bolton, F.J. (2000) Waterborne Escherichia coli O157. Appl. Microbiol. 88, 124- 132.

Chart, H. (2000) VTEC enteropathogeicity. Appl. Microbiol. 88, 12S-23S.

Cupples, A.M., Xagoraraki, I. and Rose, J.B. (2010) New molecular methods for detection of waterborne pathogens. Environmental Microbiology, Wiley Publications (book chapter).

Duris, J.W., Haack, S.K. and Fogarty, L.R. (2009) Gene and antigen markers of Shigatoxin producing $E$. coli from Michigan and Indiana river water: occurrence and relation to recreational water quality criteria. Environ. Qual. 38, 1878- 1886.

Edberg, S.C., Rice, E.W., Karlin, R.J. and Allen, M.J. (2000) E. coli: the best biological drinking water indicator for public health protection. Symp. Ser. Soc. Appl. Microbiol. 29, 106S-116S.

Elder, R.O., Keen, J.E., Siragusa, E.R., Barkocy-Gallagher, G.A., Koohmaraie, M. and Laegreid, W.W. (2000) Correlation of enterohemorrhagic Escherichia coli O157 prevalence in feces, hides and carcasses of beef cattle during processing. Proc. Natl. Acad. Sci. USA, 97, 2999- 3003.

El- Jakee, J., El-moussa, K., Mohamed, F. and Mohamed, G. (2009) Using molecular techniques for characterization of E. coli isolated from water sources in Egypt, Global Veterinaria, 3(5), 354-362.

El- Safey, M.S. (2001) Search for E. coli O157:H7 in Egyptian foods and dairy products. $P h$. D Thesis, Botany and Microbiology Department, Faculty of Science, Al-Azhar University, Egypt. 
Fagan, P.K., Hornitzky, M.A., Bettelheim, K.A. and Djordjevic, S.P. (1999) Detection of Shiga like toxin (stxl and stx2), intimin (eaeA), and enterohemorrhagic Escherichia coli (EHEC) hemolysin (EHEC hlyA) genes in animal feces by multiplex PCR. Appl. Environ. Microbiol. 65, 868- 872.

Fincher, L.M., Parker, C.D. and Chauret, C.P. (2009) Occurrence and antibiotic resistance of Escherichia coli $\mathrm{O} 157: \mathrm{H} 7$ in a watershed in North-Central Indiana. Environ. Qual. 38, 997-1004.

Fratamico, P.M., Bagi, L.K. and Pepe, T. (2000) A multiplex polymerase chain reaction assay for rapid detection and identification of Escherichia coli O157:H7 in foods and bovine feces. Food Prot. 63, 1032-1037.

Gannon, V.P., D'Souza, S., Graham, T., King, R.K., Rahn, K. and Read, S. (1997) Use of the flagellar H7 gene as a target in multiplex PCR assays and improved specificity in identification of enterohemorrhagic Escherichia coli strains. J. Clin. Microbiol. 35, 656-662.

Gannon, V.P., King, R.K., Kim, J.Y. and Thomas, E.J. (1992) Rapid and sensitive method for detection of Shiga-like toxin producing Escherichia coli in ground beef using the polymerase chain reaction. Appl. Environ. Microbiol. 58, 3809-3815.

Garcia-Aljaro, C., Muniesa, M., Jofre, J. and Blanch, A.R. (2004) Prevalence of the stx (2) gene in coliform populations from aquatic environments. Appl. Environ. Microbiol. 70, 3535-3540.

Irvine, K.N., Pettibone, G.W. and Droppo, I.G. (1995) Indicator bacteria sediment relationships: implications for water quality modeling and monitoring. In: "Modern Methods for Modeling the Management of Stormwater Impacts".W. James (Ed.), pp. 205-230. Computational Hydraulics International, Guelph, Ontario, Canada.

Kapperud, G., Vardund, T., Skjerve, Hornes, E. and Michaelsen, T.E. (1993) Detection of pathogenic Yersinia enterocolitica in foods and water by immunomagnatic separation, nested polymerase chain reactions, and colorimetric detection of amplified DNA. Appl. Environ. Microbiol. 59, 2938-2944.

Kong, R.Y., Lee, S.K., Law, T.W., Law, S.H. and Wu, R.S. (2002) Rapid detection of six types of bacterial pathogens in marine waters by multiplex PCR. Water Res. 36, 28022812.

Lee, D.Y., Shannon, K. and Lee, A.B. (2006) Detection of bacterial pathogens in municipal wastewater using an oligonucleotide microarray and real-time quantitative PCR. Microbiol Meth. 65, 453- 467.

Manafi, M. and Kremsmaier, B. (2001) Comparative evaluation of different chromogenic/flurogenic media for detecting Escherichia coli 0157:H7 in food. Int. Food. Microbiol. 71, 257-262. 
Meng, J., Doyle, M.P., Zhao, T. and Zhao, S. (2001) Enterohemorrhagic Escherichia coli. In: "Food Microbiology: Fundamentals. Doyle, M.P. (Ed.) pp. 193- 213. ASM Press, Washington DC,

Müller, E.E., Grabow, W. and Ehlers, M.M. (2003) Immunomagnetic separation of Escherichia coli O157:H7 from environmental and wastewater in South Africa Water, SA. 29,427-432.

Osek, J. (2003) Development of a multiplex PCR approach for the identification of Shiga toxin-producing Escherichia coli strains and their major virulence factor genes. $J$. Appl. Microbiol. 95, 1217-1225.

Park, S. and Durst, R.A. (1999) Immunoliposome sandwich assay for the detection of Escherichia coli $\mathrm{O} 157: \mathrm{H} 7$. Anal. Biochem. 280, 151-158.

Pebody, R.G., Furtado, C., Rojas, A., McCarthy, N., Nylen, G., Ruutu, P., Leino, P., Chalmers, R., De Jong, B., Donnelly, M., Fisher, I., Gilham, C., Graverson, L., Cheasty, T., Willshaw, G., Navarro, M., Salmon, R., Leinikki, P., Wall, P. and Bartlett, C. (1999) An international outbreak of Vero cytotoxin producing E. coli O157 infection amongst tourist: A challenge for the European infectious disease surveillance network. Epidemiol. Infect. 123, 217-223.

Quilliam, R.S., Williamsa, A.P., Averyc, L.M., Malhamb, S.K., Davey, L. and Jonesa, D.L. (2011) Unearthing human pathogens at the agricultural- environment interface: A review of current methods for the detection of Escherichia coli $\mathrm{O} 157$ in freshwater ecosystems. Agri. Eco. Environ. 140, 354-360.

Shelton, D.R. and Karns, J.S. (2001) Qualitative detection of E.coli O157 in surface waters by using immunomagnetic electrochemiluminescence. Appl. Environ. Microbiol. 67 (7), 2908-2915.

Swerdlow, D.L., Woodruff, B.A., Brady, R.C., Griffin, P.M., Tippen, S., Donnell Jr, H.D., Geldreich, E., Payne, B.J., Meyer Jr. A., Wells, J.G., Greene, K.D., Bright, M., Bean, N.H. and Blake, P.A. (1992) A waterborne outbreak in Missouri of Escherichia coli O157:H7 associated with bloody diarrhea and death. Ann. Intern. Med. 117, 812- 819.

Vernozy-Rozand, C., Montet, M.P., Lequerrec, F., Serillon, E., Tilly, B., Bavai, C., RayGueniot, S., Bouvet, J., Mazuy-Cruchaudet, C. and Richard, Y. (2002) Prevalence of verotoxin-producing E. coli (VTEC) in slurry, farmyard manure and sewage sludge in France. J. Appl. Microbiol. 93 (3), 473-478.

Waage, A.S., Vardund, T., Lund V. and Kapperud, G. (1999) Detection of low numbers of Salmonella in environmental water, sewage and food samples by a nested polymerase chain reaction assay. Appl. Microbiol. 87, 418-428. 
Wang, G., Zhao, T. and Doyle, M.P. (1996) Fate of enterohemorrhagic E. coli O157:H7 in bovine feces. Appl. Environ. Microbiol. 62(7), 2567-2570.

Wang, L., Rothemund, D., Curd, H. and Reeves, P.R. (2000) Sequence diversity of the Escherichia coli $\mathrm{H} 7 \mathrm{fliC}$ genes: implication for a DNA-based typing scheme for $E$. coli $\mathrm{O} 157: H 7$. Clin. Microbiol. 38, 1786-1790.

Willshaw, G.A., Thirlwel, J., Jones, A.P., Rowe, B. and Hickey, M. (1994) Vero cytotoxin-producing Escherichia coli $\mathrm{O} 157$ in beef burgers linked to an outbreak of diarrhoea, haemorrhagic colitis and haemolytic uraemic syndrome in Britain. Lett. Appl. Microbiol. 19 (5), 304-312.

Witham, P.K., Yamashiro, C.T., Livak, K.J. and Batt, C.A. (1996) A PCR-based assay for the detection of Escherichia coli Shiga-like toxin genes in ground beef. Appl. Environ. Microbiol. 62, 1347-1353.

(Received 10/10/ 2012; accepted $9 / 1 / 2013$ 


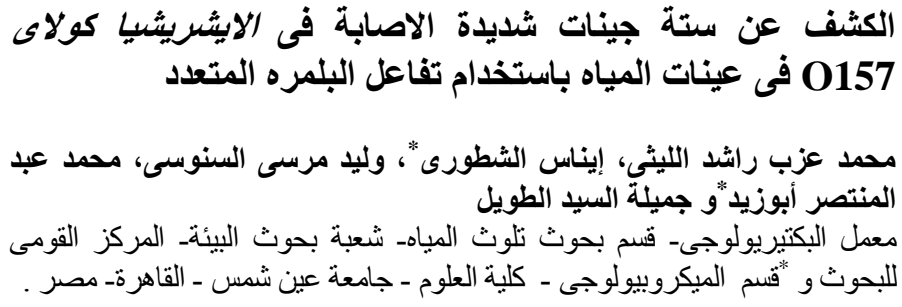

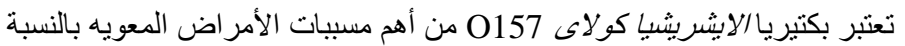

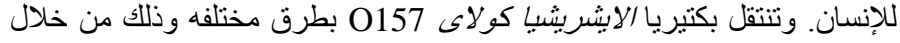

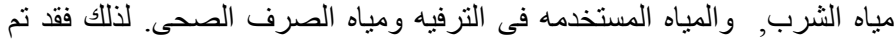

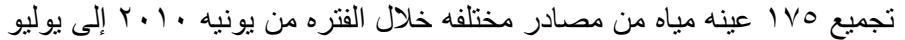

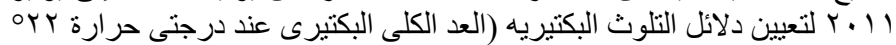

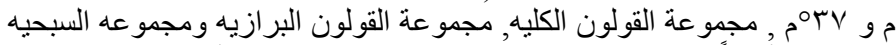

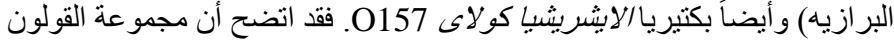

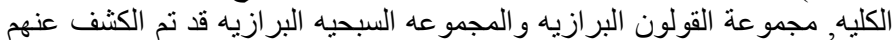

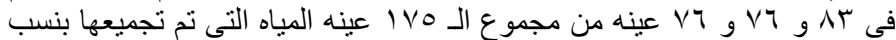

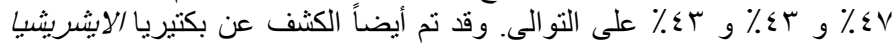

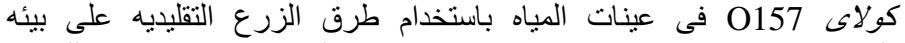

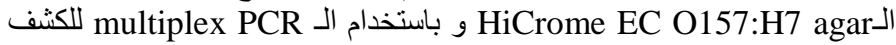

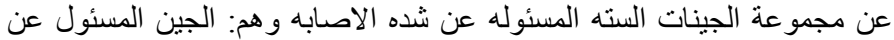
افراز سموم الثيجا ا ويسمى (stxl)

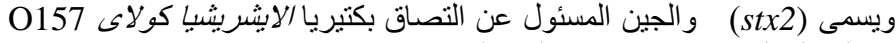

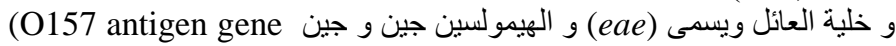

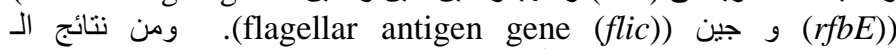

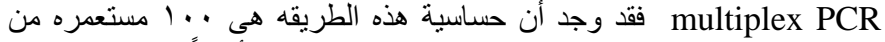

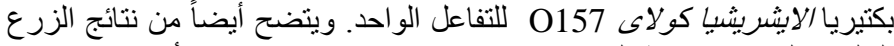

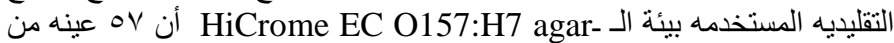

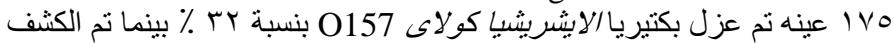

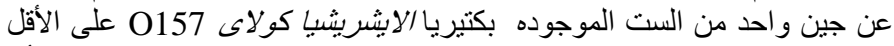

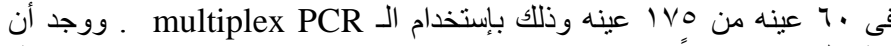

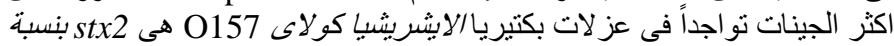

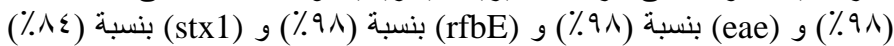

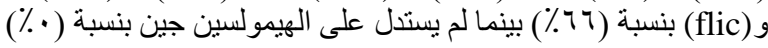

